\title{
PARADIGMA PEMIKIRAN TEOLOGI MAHASISWA FAKULTAS USHULUDDIN IAIN IMAM BONJOL PADANG
}

\author{
Ermagusti \\ e-Mail : ermagusti2013@gmail.com \\ UIN Imam Bonjol Padang
}

\begin{abstract}
Abstrak : Penelitian ini mencoba menggali corak pemikiran keagamaan mahasiswa. Adapun pemikiran keagamaan yang menjadi fokus penelitian ini adalah Ilmu teologi Islam atau disebut Ilmu kalam atau Ilmu Tauhid. Teologi Islam yang dimaksud adalah Ilmu yang membicarakan bagaimana persepsi manusia tentang Tuhannya dan bagaimana pula hubungan manusia dengan TuhanNya. Menurut Harun Nasution ( 1989:136) mempelajari teologi Islam merupakan suatu keharusan agar seseorang punya landasan aqidah yang kuat, yang kokoh, sehingga tidak mudah terombang ambing oleh peredaran zaman
\end{abstract}

Kata kunci : Pemikiran, Teologi

\section{Pendahuluan}

Berbicara masalah teologi
dalam Islam, berarti berbicara mengenai ajaran dasar atau pokok dari Agama Islam. Teologi membahas berbagai persoalan yang berhubungan dengan masalah ketuhanan, dan kewajiban manusia terhadap Tuhan. Ilmu yang mempelajari tentang ajaran dasar dalam Islam ini disebut dengan Ilmu Ushuluddin, Ilmu al-Tauhid, Ilm al-Kalam. Ilmu ini membahas persoalan yang berhubungan dengan wujud Allah, sifat-sifat yang wajib ditetapkan kepadaNya, dan sifat-sifat yang wajib dinafikan kepadaNya dan tentang rasul-RasulNya ( Muhammad Abduh, 1979: 37)

\section{Mahasiswa} Fakultas Ushuluddin mempelajari ajaran dasar ini dalam mata kuliah Teologi yang terdiri dari mata kuliah Ilmu Tauhid dan Ilmu Kalam merupakan mata kuliah mayor yang harus diambil oleh setiap mahasiswa Fakultas Ushuluddin IAIN Imam Bonjol. Adapun tujuan mata kuliah ini adalah agar mahasiswa mengenal dan mampu memahami dengan baik corak pemikiran Teologi yang berkembang dalam Islam untuk memahami persoalan Aqidah Islamiyah.

$$
\text { Mahasiswa diperkenalkan }
$$
perbedaan pemikiran yang terjadi di kalangan umat Islam, yang semuanya itu punya landasan pemikiran yang dan punya alasan yang terdapat dalam al-Quran dan Hadis Nabi. Dalam kurikulum dan silabus Ilmu Kalam yang diajarkan untuk Mahasiswa Fakultas Ushuluddin tergambar bahwa materi silabus tersebut dimulai dari Sejarah timbulnya persoalan Teologi dalam Islam, sampai kepada aliranaliran yang berkembang dikalangan umat Islam zaman klasik sampai sekarang yaitu aliran Khawarij, Murjiah, Syiah, Jabariah, Qadariah, Muktazilah, Asyariyah, Maturidiah dan 
Salafiah dan Wahabiah dan aliran modern lainnya. Dengan demikian, mahasiswa mengenal aliran-aliran yang berkembang dalam Islam dan corak pemikirannya, diharapkan mahasiswa mampu menganalisa aliran-aliran yang berkembang di tengah umat Islam saat sekarang ini.

Pemikiran teologi yang dianut berpengaruh terhadap produktifitas dan hasil kerja mereka.Dalam teologi terdapat dua ajaran yang berkaitan erat dengan produktifitas dan etos kerja mereka. Pertama, ajaran yang mengatakan bahwa nasib manusia sudah ditentukan oleh Allah sejak azalinya. Orang yang berpaham seperti ini dengan sendirinya produktifitasnya akan kurang, paham ini disebut dengan Fatalisme atau Jabariah. Keyakinan. bahwa nasib sudah ditentukan Tuhan, membuat orang jadi fatalis dan statis. Hal itu akan menimbulkan suatu keyakinan bahwa sesuatu diatur oleh Tuhan berdasarkan Kehendak Mutlaknya. Kedua, ajaran yang berpahamkan bahwa manusialah yang. menciptakan perbuatannya, sehingga manusia itu bebas melakukan apa yang diingininya. Menurut paham ini gagal atau berhasilnya usaha seseorang bukan tergantung kepada kehendak 3 . Tuhan semata, tetapi lebih banyak ditentukan oleh sikap dan usaha manusia. Paham ini akan menghasilkan produktifitas yang tinggi, disebut dalam teologi Islam dengan Faham Qadariah dengan filsafat hidup rasionalnya.
Karena itu, secara empiris perlu dilakukan penelitian tentang pemikiran teologi mahasiswa Fakultas Ushuluddin IAIN Imam Bonjol Padang, yang pada umumnya mereka telah mendapatkan pengetahuan agama bidang ilmu teologi Islam yang mereka peroleh di Fakultas Ushuluddin. Di samping itu, tuntutan untuk mengkaji ulang (re-thingking) pemikiran keagamaan, merupakan suatu keharusan agar materi ilmu keislaman yang diajarkan di Perguruan Tinggi ini kepada mahasiswa dapat diaplikasikannya dalam kehidupan.

\section{Rumusan Masalah}

Berdasarkan latar belakang masalah di atas, maka masalah pokok dalam penelitian ini dapat dirumuskan sebagai berikut:

Bagaimana corak Pemikiran Teologi Mahasiswa Fakultas Ushuluddin IAIN Imam Bonjol Padang tentang perbuatan yang ia lakukan, apakah perbuatan itu diyakini berasal dari kehendak dan kemauannya sendiri atau Allah yang menghendaki untuk melakukan.

Bagaimana corak Pemikiran Mahasiswa Fakultas Ushuluddin IAIN Imam Bonjol Padang tentang konsep iman, apakah diyakini iman dan amal itu punya hubungan atau tidak.

Bagaimana corak pemikiran mahasiswa Fakultas Ushuluddin IAIN Imam Bonjol Padang tentang takdir, apakah mereka menunggu takdir dari Allah secara pasrah atau mereka berusaha secara aktif untuk mendapatkan takdir yang baik. 


\section{Tujuan Penelitian:}

1. Untuk mengetahui lebih jauh bagaimana corak pemikiran teologi mahasiswa tentang perbuatan yang ia lakukan, apakah mahasiswa punya keyakinan bahwa setiap tindak tanduknya sudah ditentukan oleh Tuhan atau sebaliknya bahwa semua tindak tanduknya itu berasal dari kemauan dan kehendaknya sendiri

2. Untuk mengetahui lebih jauh tentang konsep iman yang dipahami oleh mahasiswa, apakah iman itu punya hubungan dengan amal atau terpisah.

3. Untuk melihat sejauh mana pemikiran teologi mahasiswa tentang takdir dan hubungannnya dengan sikap dan perilakunya dalam kehidupan sehari-hari.

\section{Landasan Teori}

Secara lughawi, teologi berarti ilmu tentang Tuhan atau disebut juga dengan Ilmu Ketuhanan. Dari makna kata ini dipahami pada dasarnya Teologi merupakan ilmu yang membahas tentang Tuhan atau yang terkait dengan persoalan ketuhanan ( Hamzah Ya'kub, 1984:21). Dalam Islam Teologi itu disebut juga dengan ilm al-Tauhid atau 'ilm al-kalam, pembahasannya berkisar disekitar ajaran pokok dalam suatu agama ( Harun Nasution, 1986: ix) yaitu masalah ketuhanan, kewajiban-kewajiban manusia terhadap Tuhan dengan memakai akal dan wahyu untuk memperoleh kedua pengetahuan tersebut.

Siapapun yang memberi defenisi tentang teologi itu persoalannya hanya berkisar disekitar ketuhanan dan hal-hal yang berhubungan dengan Tuhan. Persoalan tersebut adalah pesoalan yang mendasar yang dibahas dalam suatu agama. Oleh karena itu orang yang ingin mengetahui ajaran agamanya secara mendalam, perlu mempelajari teologi yang terdapat dalam agama yang dianutnya. Pendekatan yang dipakai dalam membahas persoalan teologi atau ketuhanan adalah pendekatan akal pikiran, terutama dalam memahami fenomena ketuhanan di alam semesta, di samping pendekatan wahyu.

Teologi Islam sebagai salah satu disiplin ilmu telah tumbuh dan berkembang sehingga menjadi bahagian dari tradisi kajian tentang agama Islam pada zaman klasik, bahkan ilmu ini pernah menempati posisi yang cukup terhormat dalam tradisi keilmuan pada masa pemerintahan al-Makmum yang mengakui salah satu dari aliran teologi dalam Islam - Muktazilahsebagai mazhab resmi yang dianut oleh negara.

Prediket yang disandang Muktazilah waktu itu tidak telepas dari konsep tauhid sebagai concern mereka, yang dijabarkan secaras filosofis dalam ajaran pokoknya yang dikenal dengan al-ushul al- 
khamsah. Implikasi dari ajaran yang bersifat rasional ini dapat membawa umat Islam berkebudayaan dan berpradaban tinggi ( high culture), yang membawa umat Islam ke priode kreatif dan dinamis. Priode ini berlanngsung lebih kurang lima abad, yang selanjutnya dapat mewujudkan ilmu penegetahuan dan teknologi. Tidak dapat disangkal bahwa gerakan Muktazilah telah memberikan sumbangan internal yang besar terhadap perkembangan pemikiran rasional dalam Islam yang membawa umat Islam maju dalam bidang ilmu pengetahuan dan teknologi.

Yang perlu disadari, Teologi Islam itu bukan dalam artian agama sebagai suatu ajaran, hanya merupakan pemikiran reflektif seorang yang beriman mengenai imannya dalam rangka memperkokoh iman yang telah diresapinya. Karena itu rumusan teologi Islam sebagai rumusan akal pikiran manusia akan berbeda sesuai dengan situasi dan kebutuhan generasi pada kurun sejarah tertentu.

Tidak mustahil, jika generasi yang hidup pada zaman dimana stuasi sosial, politik dan ekonomi yang sudah berbeda, akan mempengaruhi pola corak teologi yang dianut dan berkembang waktu itu. Muncullah dikalangan umat Islam itu aliran-aliran teologi, ada yang bersifat rasional ada pula yang bersifat tradisional dan ada pula yang bersifat keduanya. Semua corak ini tidak bertentangan dengan dasar Islam. Dengan demikian orang yang memilih salah satu dari aliran itu sebagai teologi yang dianutnya, tidaklah menyebabkan ia keluar dari Islam.

Teologi Rasional adalah pemikiran yang bersifat filosofis dan ilmiah yang muncul dikalangan pemikiran Islam klasik. Penganut teologi ini hanya terikat pada dogma -dogma yang dengan jelas lagi tegas disebut dalam ayat al-Quran dan Hadis Nabi SAW yaitu suatu ayat yang tidak bisa diinterpretasikan lagi, menurut Harun Nasution disebut ayat yang qath'i al-dalalah.

Sebaliknya, pemikiran teologi tradisional tidak terikat tidak hanya pada dogma yang jelas dan tegas dalam al-Quran dan Sunnah ( qath'i), tetapi juga pada ayat yang mempunyai arti zhanni, yaitu ayatayat berpeluang untuk ditafsirkan. Melihat dari ciri-ciri teologi ini, maka pemikiran dalam Teologi Asy'ariyah dapat dikelompokan kepada teologi yang bercorak tradisional, ia lebih cenderung bersifat teocentris, dimana daya yang ada pada manusia tidak dapat menentukan berhasil atau tidaknya suatu usaha dan perbuatan manusia, karena Tuhan yang menentukannya, manusia dalam hal ini sangat bergantung kepada kehendak mutlak Tuhan. Sebaliknya Aliran Muktazilah dapat dikelompokkan kepada teologi yang bercorak rasional. Dalam teologi ini daya 
yang ada pada manusia lebih dominan dalam mewujudkan suatu perbuatan, karena itu Muktazilah berpaham Qadariah, sementara Asy'ariyah lebih mendekati kepada Jabariah.

\section{Jenis Penelitian}

Jenis penelitian ini adalah penelitian kualitatif dengan menggunakan analisis deskriptif yaitu menggambarkan suatu objek peristiwa tertentu sebagaimana adanya. Penelitian ini bermaksud untuk membuat diskripsi, mengenai pola pikir dari mahasiswa. Dalam Penelitian Kualitatif, peneliti sendirA. adalah merupakan alat utama dalam pengumpulan data, karena penelitilah yang mampu berhubungan dengan objek penelitian atau responden. Dengan kata lain, penelitilah yang mampu memahami nilai-nilai yang terkandung dalam objek penelitian serta memahami makna interaksi antar objek, membaca dan menilai apa yang terkandung dalam ucapan atau perbuatan responden. Pihak yang dijadikan informan dalam penelitian ini adalah pendapat dari mahasiswa Fakultas Ushuluddin IAIN Imam Bonjol yang terdiri dari mahasiswa Aqidah Filsafat, Perbandingan Agama, Tafsir Hadis yang telah mengambil mata kuliah teologi, dengan memakai teknik purposive sampling.

Adapun teknik pengumpulan data yang dipakai dalam penelitian ini adalah wawancara, dengan para mahasiswa Fakultas Ushuluddin IAIN
Imam Bonjol, dengan mengajukan sejumlah daftar pertanyaan yang telah dipersiapkan berdasarkan jenis data yang dibutuhkan. Di samping itu peneliti juga memakai kuestioner/ angket, agar peneliti punya gambaran terlebih dahulu arah pemikiran mahasiswa, setelah itu peneliti mendalami pemikiran mahasiswa dengan wawancara.

Setelah data terkumpul, kemudian dilakukan pengolahan dan analisis data yang dirumuskan dalam bentuk katakata selanjutnya baru di ambil suatu kesimpulan

\section{Corak Pemikiran Mahasiswa} Tentang Perbuatan Manusia

Kecenderungan pemikiran mahasiswa dalam memahami perbuatan manusia cenderung berpaham rasional. Menurut mereka untuk terwujudnya suatu perbuatan adalah semata-mata kemauan dan kehendak manusia, Tuhan dalam hal ini hanya pencipta daya di saat manusia diciptakan. Sementara dalam pemakaian daya ini manusia bebas melakukan atau tidak melakukannya. Sukses atau gagalnya suatu usaha manusia sangat tergantung kepada usaha yang dilakukan manusia sebagaimana yang disampaikan $\mathrm{FN}$ mahasiswa Perbandingan Agama yang harus dilakukan seseorang dalam mencapai kesuksesan adalah berusaha dan berdoa, karena Allah tidak akan merubah nasib suatu kaum kalau manusia itu sendiri tidak berusaha untuk merubahnya, demikian dia 
mengutip ayat al-Quran ( wawancara, 13 Nofember 2014) Begitu juga perbuatan baik dan buruk yang dilakukan tergantung kepada pilihan manusia sendiri, disinilah fungsinya akal pemikiran yang ada pada manusia itu.

Manusia ingin sukses, maka dia harus berusaha maksimal sesuai aturan dan ketentuan yang ada, setelah itu dia baru bertawakal kepada Allah atas hasil usaha tersebut. Sebaliknya kalau dia gagal, maka dia akan introspeksi sebab dari kegagalannya, mungkin ada dari usahanya itu yang belum mengikuti aturan yang ada. Dia tidak bisa menyalahkan siapa-siapanya, kecuali dia merobah sikap dan cara yang dia lakukan, sebagaimana yang disampaikan oleh IS mahasiswa Tafsir Hadis, bahwa kalau usaha yang kita lakukan belum mencapai keberhasilan atau gagal, kita harus introspeksi diri, mungkin usaha yang kita lakukan belum maksimal, karena itu kita tetap berusaha tidak boleh putus asa, setelah itu baru kita bertawakkal.

Ada beberapa orang dari mahasiswa yang berpaham tradisional, bahwa perbuatan yang dilakukan oleh manusia terwujud karena kehendak mutlak Tuhan. Untuk mencapai kesuksesan, cara yang harus dilakukan adalah perbanyak doa, mudabB. mudahan Tuhan memberikan kesuksesan kepada manusia. Pemikiran mahasiswa ini setelah ditelusuri melalui wawancara yang dilakukan bahwa mereka berpendapat bahwa Tuhan itu Maha Berkehendak Mutlak terhadap makhluk ciptaannya. Kalau Tuhan berkehendak manusia itu sukses dan berhasil ada-ada saja jalan untuk hal tersebut. Semuanya di luar kekuasan dan kemampuan manusia, karena kekuasaan Tuhan itu di atas segala-galanya. Gagal atau berhasilnya usaha manusia sangat ditentukan oleh kehendak mutlak Tuhan. Sebagaimana yang disampaikan oleh MG mahasiswa Perbandingan Agama adalah manusia tidak memiliki kuasa apa-apa dalam perbuatannya, buktinya saja seperti masa yang berganti disekililing kita, lihat saja anak-anak yang tumbuh menjadi dewasa, akhirnya tua renta dan tutup usia, awalnya kuat dan akhirnya lemah, hidup dan mati hal itu adalah bukti mendasar bahwa manusia tidak memiliki kekuasaan dalam berbuat. ( wawancara, 12 Nofember 2014)

Alasan yang disampaikan bahwa, betapa banyaknya manusia berbuat untuk mencapai sesuatu tujuan, tetapi tidak kunjung berhasil. Hal ini menandakan bahwa perbuatan manusia itu bukan manusia yang mewujudkannya, tetapi Tuhanlah yang berkehendak yang sesungguhnya. Kekuasaan Tuhan memang mutlak dalam hal ini, manusia ibarat wayang yang dimainkan oleh dalangnya.

\section{Corak Pemikiran Mahasiswa tentang Iman \\ Mayoritas mahasiswa Fakultas Ushuluddin mengatakan iman itu tidak sekedar tasdiq billah saja, tetapi iman itu adalah tasdiq billah, ikrar bi lisan dan amal perbuatan. Artinya mereka}


membenarkan Allah dan Rasul di hati dan mengucapkan dengan lisan serta dibuktikan dengan amal perbuatan. Walaupun ada beberapa orang dari mahasiswa yang berpendapat bahwa iman itu cukup dengan meyakini Allah dan Rasul Muhammad SAW. Pendapat dari sebahagian kecil dari mahasiswa ini tentu punya alasan, yang sesungguhnya tidak bisa dijadikan dasar. Sebagaimana yang dijelaskan oleh AS mahasiswa Tafsir Hadis, bahwa dulu sebelum kita kuliah pemahaman kami tentang iman adalah meyakini seyakin-yakinnya akan Allah dan Rasulnya, tetapi setelah kami kuliah ini, kami memahami iman tidak hanya berarti meyakini saja tapi ikrar dengan lisan dan amal dengan perbuatan (wawancara, 17 Nofember 2014) Lebih lanjut RK Mahasiswa Tafsir Hadis menjelaskan di samping keyakinan kepada Allah dan Rasul Muhammad SAW, kita juga harus melaksanakan amal perbuatan yang disuruh oleh Allah mengerjakannya baik yang wajib atau yang sunnat, sebagai ungkapan kepatuhan dan ketaatan kita kepada Allah wawancara, 17 Nofember 2014)

Antara iman dan amal ibadah yang dilakukannya terdapat hubungan kausalitas (sebab akibat), makin kuat iman pada diri seseorang, maka makin baik dan tinggi frekuensi ibadahnya. Makin baik dan sempurna ibadahnya, maka makin mantap pula keimanan dalam dirinya. Orang yang rajin beribadah, imannya akan bertambah kuat dan mantap, sehingga tidak satupun yang dapat mempengaruhi dan menggoyahkan imannya. Sebaliknya makin kurang iman seseorang makin berkurang pula frekuensi ibadahnya, selanjutnya makin dangkal pula iman seseorang tersebut.

Apabila pelaksanaan ibadah seseorang dilandasi oleh keimanan yang terdapat dalam diri seseorang mukmin akan dapat memberi dampak positif terhadap sikap dan perilaku seorang muslim. Seorang yang melaksanakan sholat, dia akan menjauhkan diri dari perbuatan keji dan munkar, sebagaimana yang dijelaskan Allah dalam surat alAnkabut:45. Apabila sholat dilaksanakan dengan baik dan benar disertai dengan penuh keimanan kepada Allah. Sholat yang dilaksanakan dengan keimanan kepada Allah akan mendekatkan jiwa seseorang kepada Allah. Kedekatan itu akan melahirkan perasaan dan keyakinan bahwa ia selalu diperhatikan di awasi oleh Allah SWT, karena itu ia tidak akan melakukan perbuatan jahat dan munkar.

Amal perbuatan dipandang sebagai bukti iman dalam bentuk perbuatan, demikian juga pengakuan secara lisan merupakan bukti iman dalam bentuk ucapan. Dalam pemikiran teologi tradisional bahwa kekuatan akal dalam teologi ini kecil, maka wahyulah yang menjelaskan kepada manusia tentang kewajibankewajiban manusia kepada Tuhan. Manusia harus menerima dan meyakini penuh penghabaran wahyu tersebut. 
Agaknya inilah yang dimaksud dengan tasdiq billah oleh aliran Asy'ari yang bercorak tradisional.

\section{Corak Pemikiran Mahasiswa Tentang Takdir}

Sebagaimana juga yang terjadi dikalangan mutakallimin terdapat perbedaan pendapat dalam memahami masalah takdir. Di antaranya ada yang berpendapat bahwa manusia tidak mempunyai qudrat dan iradat sedikitpun, manusia adalah sebagai tempat perbuatan Allah, ibarat bulu yang beterbangan, inilah pendapat Jabariyah. Sementara pendapat lain yaitu golongan Qadariyah mengatakan bahwa manusia punya qudrat dan iradat yang diberikan Allah kepadanya. Dengan demikian manusia sanggup melakukan perbuatan berdasarkan kekuatan dan kehendaknya sendiri.

Demikian pula halnya dengan pemikiran mahasiswa Fakultas Ushuluddin tentang takdir, sebagaimana yang dijelaskan oleh FN mahasiswa Perbandingan Agama bahwa takdir dipahami adalah ketentuan Allah terhadap makhluknya atas segala sesuatu, manusia diberi Allah potensi atau kemampuan untuk melakukan perbuatan berdasarkan kemauan dan kehendaknya sendiri. Seorang yang beruntung di dunia ini yang bernasib baik karena usaha dan doanya kepada Allah (wawancara, 12 Nofember 2014) Pada umumnya pemikiran mahasiswa dalam masalah takdir ini adalah berpaham qadariah yaitu rasional.
Demikian, kalau seseorang menginginkan takdir baik, maka mayoritas dari mahasiswa mengatakan harus dengan usaha maksimal menuruti aturan Nya, setelah itu baru tawakal sambil berdoa kepada Allah semoga Allah memberikan sesuatu yang terbaik kepadanya. Inilah gambaran pemikiran mahasiswa yang rasional. Agaknya pemikiran mahasiswa ini dipengaruhi oleh tantangan yang semakin berat dalam hidup, maka yang harus dilakukan adalah menembus tantangan ini dengan usaha dan perjuangan yang maksimal.

Namun ada segelintir mahasiswa yang berpaham Jabariah, kita terima semua takdir Allah secara pasrah karena Allah telah menentukan nasib manusia itu sejak dari zaman azali, kita tidak perlu mencari takdir Allah, karena takdir itu pasti datang karena Allah sudah menentukan untuk kita. Usaha apapun yang akan dilakukan manusia semuanya akan percuma begitu saja. Faktor yang menyebabkan mahasiswa berfikiran seperti ini, adakalanya karena keterbatasannya dalam hidup, baik keterbatasan dalam masalah ekonomi yang tidak bisa banyak berbuat, tidak bisa mengakses kemajuan dari berbagai aspek. Adakalanya juga disebabkan keterbatasan pengetahuan yang mereka miliki, sehingga mereka tidak bisa berbuat apa-apa kecuali menerima segala sesuatu apa adanya.

Yang menarik disini, kalau takdir seseorang itu ternyata tidak baik, seperti banyak penderitan, kesuksesan 
yang diharapkan masih jauh, maka dia mengatakan bahwa Allah yang menentukan semuanya ini. Tetapi kalau takdirnya baik, dia menjadi orang sukses, dan dapat menikmati kemewahan dalam kehidupan, apalagi dia menjadi orang yang terpandang, maka dia akan mengatakan bahwa semua ini atas usaha yang dilakukan secara maksimal.

Menurut peneliti, latar belakang pendidikan, sosial dan budaya juga memberi pengaruh terhadap corak berfikir mahasiswa tersebut. Kalau dia berasal dari keluarga yang berpendidikan dari kalangan ekonomi yang baik, maka corak pemikirannya cenderung rasional, karena segala tantangan yang dihadapinya bisa dilalui dengan baik. Sebaliknya, mahasiswa yang berasal dari kalangan keluarga yang tidak berpendidikan dan ekonomi yang kurang menguntungkan, maka kecederungan pemikirannya tradisional. Hal ini disebabkan karena ketidakmampuannya menghadapi tantangan dalam hidup, sehingga terkesan dia menyerah kepada takdir.

\section{Kesimpulan}

Dari Berdasarkan kajian dan analisis dari hasil penelitian yang telah dilakukan tentang paradigma pemikiran teologi mahasiswa Fakultas Ushuluddin, maka secara umum dapat disimpulkan bahwa:
1. Pemikiran mahasiswa tentang perbuatan manusia (af'alul 'ibad), cenderung rasional, Gagal atau berhasilnya manusia tergantung kepada uasaha yang dilakukan manusia tersebut hampir semuanya sependapat. Tetapi kalau terjadi kegagalan manusia dalam usahanya, maka yang cenderung berfikiran tradisional memahaminya, sudah ketentuan Allah .

2. Pemikiran mahasiswa dalam aspek iman, pada umumnya berpendapat bahwa iman itu adalah tasdiq billah, dibuktikan dengan ucapan lisan (takrir bi lisan) dan amal perbuatan. Antara iman dan amal ibadah yang dilakukannya terdapat hubungan kausalitas, makin kuat iman seseorang, maka semakin baik dan tinggi frekuensi ibadahnya, semakin sempurna ibadahnya, maka semakin bagus kualitas imannya.

3 Takdir dipahami oleh mahasiswa sebagai ketentuan Allah terhadap makhluknya atas segala sesuatu, manusia diberi potensi atau kemampuan untuk melakukan perbuatan berdasarkan kemauan dan kehendaknya sendiri. Kalau seseorang mendapatkan takdir baik, dia menjadi orang sukses, orang terpandang, pada umumnya mahasiswa mengatakan hasil usaha maksimal sesuai dengan aturan yang ada, tetapi kalau takdirnya yang didapat tidak baik, banyak penderitaan dalam hidup, dia mengatakan Allah telah menentukan 
nasib kita seperti ini, disinilah menariknya pemikiran mahasiswa.

\section{Saran-Saran}

1. Disarankan kepada Dosen Ilmu kalam, agar kiranya lebih mengembangkan penelitian teologi ke aspek kehidupan masyarakat luas, karena pola pikir seseorang dalam teologi sangat terkait dengan produktifitas dan etos kerja.

2. Kepada kelompok dosen konsorsium Ilmu Tauhid/ Kalam agar merancang silabus yang aplikatif dan dinamis dan menambah bobot SKS kuliah teologi untuk semua Fakultas.

\section{DAFTAR KEPUSTAKAAN}

Al-Syahrastani, al-Milal wa al-Nihal, Dar a-Fikr, Libanon, Beirut, tt

Abu Zahrah, Tarikh al-Mazahib alIslamiyah, Mathbaah al-mishra, 1965

Ahmad Hanafi, Pengantar Teologi Islam, Pustaka al-Husna, Jakarta, 1980 , Teologi Islam ( Ilmu Kalam), Bulan Bintang, Jakarta, 1983

Ali, Musthofa al-Ghurabi, Tarikh alFiraq al-Islamiyah, Maktabah alMuktabarah al-misra, tt

Amin Abdullah, Falsafah Kalam di Era Posmodernisme, Pustaka Pelajar, Yogyakarta, 1995

Creswell, John W, Reseach Design, Pendekatan Kualitatif, Kuantitatif dan Mixed, Penerjemah Ahmad Fawaid,
Pustaka Pelajar, Yogyakarta, 2010

Fahri Ali dan Bachtiar Efendi, Merambah Jalan Baru Islam, Merekonstruksi Pemikiran Islam Indonesia, Mizan Bandung, 1990

Harun Nasution, Teologi Islam, AliranSaliran Sejarah, Analisa Perbandingan, UI Press, Jakarta, 1986

Akal dan wahyu dalam Islam, UI Press, Jakarta, 1986 Pembaharuan dalam Islam, Bulan Bintang, Jakarta, 1987

Islam Rasional, Gagasan dan Pemikiran, Mizan Bandung, 1995. Muhammad Abduh dan Teologi Rasional, Ui Press, Jakarta, 1987

Harahap, Syahrin, Metodologi Studi Penelitian Ilmu-Ilmu Ushuluddin, Radja Grafindo Persa, Jakarta, 2002

Moleong, Lexy J, Metode Penelitiann Kualitatif, Remaja Rosda Karya, Bandung, 1994

Masyhur Amin, Teologi Pembangunan, Paradigma baru Pemikiran Islam, LKPSM Yogyakarta, 1989

Montgomerry Watt, Pemikiran Teologi Islam, alih bahasa Umar Basalim, Midas Surya Grafindo, Jakarta, 1987

Sobur, A. Kadir, Qadar dan Ikhtiar dalam Ilmu Kalam, Pruden Media, Yogyakarta, 2014

Surakhmad, Winarno, Pengantar Penelitian Ilmiah, Tarsito, Bandung, 1985

S. Nasution, Motode Research, Jemmars, Bandung, 1987 
Kaelan, MS, Metode Penelitian Kualitatif bidang Filsafat,

Paradigma, Yogyakarta, 2005 